\title{
A Study on the Sustainable Development of Rural Finance in China
}

\author{
Xiaochan Lin \\ Harbin university of Commerce in Heilongjiang province China
}

11088678@qq.com

\begin{abstract}
Keywords: Rural finance; Sustainable development; Development research; China's agricultural development; Finance system
\end{abstract}

\begin{abstract}
The sustainable and healthy development of rural finance is an important guarantee for China's agricultural and rural development, the lack of the support of rural finance; China's agricultural development will be very slowly. But because of our country's public finance system is not perfect; the financial policy which supports the development of rural finance faces the dilemma of supply and demand imbalance, which directly restricts the sustainable development of rural finance in our country. Based on this, the construction of a sound public finance support system has become one of the important breakthroughs to promote the sustainable development of rural finance in China.
\end{abstract}

\section{Introduction}

In twentieth Century, the rural finance attracted the attention of scholars, the industrial revolution promoted the development of productive forces, promote the process of urbanization in western countries, but in the rapid development of the city at the same time, the efficiency of agricultural production has not been significantly improved, the income of farmers is not high growth, in this context, scholars to analyze reasons restricting the agricultural development, finally draw a conclusion: agriculture has the characteristics of long production cycle, slow investment, the bank for agriculture is not high degree of concern, for the agricultural financial support is relatively small, the lack of rural finance is an important reason for restricting agricultural development. Since then, rural finance has begun to receive the attention of western scholars and countries, and give a comprehensive study of rural finance; the concept of rural finance is also put forward at this time. Based on the concept of finance, it can be concluded that the concept of rural finance is closely related to the activities of rural money, rural credit, rural deposits, rural exchange, rural credit and other economic activities.

\section{Theoretical Summary}

In 90s, after the world has experienced a severe financial crisis, since the world began to realize the importance to establish and perfect the financial market system, and gradually take measures to establish or improve their financial market. But compared with the city, the rural endowment has obvious gap, weak and agricultural production cycle is longer and agriculture itself, which is difficult to cultivate rural areas like the city of mature and perfect financial market system. Based on this, a lot of domestic and foreign students believe that the government must play a leading role in the rural financial market, in order to avoid the problems and defects in the development of the rural financial market. In this regard, the United States economist Stiglitz put forward the theory of imperfect competitive market has become an important basis for guiding the development of rural financial markets.

In the imperfect competition market theory, compared with developed countries, the financial markets in the developing countries in incomplete competition, due to the asymmetry of information, financial institutions in the loan process, it is difficult to effectively and fully understand the relevant information of the borrower, the developed financial market has some defects. In order to avoid the negative effect of the market mechanism, the government should play a role in the development of the financial market. Imperfect competition theory provides a 
theoretical reference for the government to intervene in the rural financial market of our country, the scope of rural area of our country is very extensive, farmers have a greater demand for financial services, but according to our country's farmers to provide financial services institutions is not much. At the same time, because of China's rural credit system is not perfect, which makes a lot of farmers in personal information and no access to the credit system, not only that, in the financial institutions for the farmers loan process, because farmers is difficult to provide effective and accurate personal information and full security, making the rural financial service does not play service the "three rural" role. It can be seen that the imperfect competition theory is consistent with the actual situation of China's rural financial development, on the basis of the theory to consider the construction of rural financial market Chinese, requires play to the functions of the government intervention in the construction of rural financial market in the leading role, to guide the rural financial market healthy and sustainable development.

\section{The Current Situation of China's Rural Financial Sustainable Development}

In recent years, China's rural financial reform deepening, rural financial development has made some achievements, but at this stage of financial institutions of China's economic backwardness in rural areas where the financial development level is still not enough attention. According to the relevant statistics, by the end of 2015, China's banking total deposits of urban and rural residents exceeded 100 trillion yuan, of which city residents deposit ratio is about $80 \%$, the proportion of rural residents deposits is about 20\%; in 2014 the annual total bank loans exceeded 90 trillion yuan, of which city loans accounted for over 95\%. Rural financial development lags behind the city, the Financial Exclusion in rural areas is serious, the specific analysis is as follows:

First, geographical exclusion. Relative to the area of the city, rural areas because of its infrastructure construction lag, traffic inconvenience, the concentration degree of population is not high, the low level of economic development, in the vast rural areas of our country, banks, insurance companies, securities companies and other networks is insufficient. According to the China Banking Regulatory Commission statistics, as of the end of 2015, China's township bank financial institutions to draw a number of 4.6, the country more than 3000 villages and towns without any financial institutions outlets. Financial institutions, the lack of coverage is not deep, not all service involvement is an important cause of the supply of financial institutions in rural areas, rural financial exclusion, demand due to lack of financial institutions and financial products are not met, to bring a negative impact on China's rural output growth.

Second, conditional exclusion. For the loan risk and returns, banks and other financial institutions in foreign lending to borrowers credit records, debt paying ability and other aspects of a detailed assessment to determine the loan object and the size of the loan, in the mortgage conditions also requires lenders to provide corresponding collateral, in order to reduce the risk of bank loans, the borrowers to prevent business poor bank loan will not be repaid to the bank and find the loss. But the construction of China's vast rural areas of social credit system is slow, has not yet formed a sound credit evaluation mechanism, banks can not be a scientific evaluation system for farmers, leading financial institutions in rural areas, business risk is too high, the enthusiasm of financial institutions to carry out business activities in rural areas is not high.

Third, price exclusion. At present, commercial banks because of the risk of income asymmetry is not willing to enter the rural areas to carry out the business, financial services in rural areas, most of the policy banks, postal savings banks and rural credit cooperatives provide. However, the Agricultural Development Bank of China is usually provided large loans to agricultural production for farmers, small amounts of money demand which is not considered; although the bank across the vast rural areas of China, but its role in the rural financial system is more "agricultural economy blood machine" role, not only keep the phenomenon of the loan outstanding. Colleagues, affected by the current financial system, rural credit cooperatives usually adopt the provisions of the central bank 2 times to 3 times of the loan interest rate benchmark interest rate loans to rural financial products, the price is beyond farmers expected to lead farmers to give up part of the financial services. 


\section{Improve the Rural Financial Service System in China}

In view of the deficiency of the current situation of China's rural financial development, combined with the experience and Enlightenment of the United States financial support for agricultural development, to improve the construction of rural financial service system in our country can proceed from the following aspects:

Enhance the Concept of Rural Financial Development. Improve the construction of rural financial system. First of all, the government should be aware of the objective situation of China's rural financial development lags behind, fully realize the importance of the development of rural finance to ensure stable agricultural production, promote rural economic growth, improve the degree of attention to the development of rural finance, strengthening the concept of rural financial development. Secondly, the government should improve the rural financial system construction, on the one hand, the government should establish and improve the rural financial legal regulations, considering the rural development of new changes and future development needs, to develop the rural finance and the revision of laws and regulations, improve the defects of the existing financial laws and regulations; on the other hand, the government should strengthen the construction of evaluation the mechanism of credit in rural areas, the establishment of social honor unified information management platform, to provide objective reference for commercial banks and other financial institutions to carry out financial services in rural areas.

Strengthen the Internal Financial System. Strengthen the rural financial support. For rural credit cooperatives, private loans and other rural financial internal system, the government in strengthening the supervision of their colleagues, but also to increase their support. By now, the government should continue to strengthen the three rural credit cooperatives service concept, in the reform of rural credit cooperatives should continue to take root in rural areas, rural services, strengthening the property rights reform of rural credit cooperatives to continue to take root in rural areas, rural services, strengthening the property rights reform of rural credit cooperatives, accelerate the pace of joint-stock reform to meet the conditions the rural credit cooperatives, clarify the property right, in order to adapt to the development of rural financial market economic system requirements. Secondly, the government should strengthen the private lending and other non formal financial institutions lending behavior, improve relevant laws and regulations, unified standards of private capital into the financial market and procedures to protect the legitimate interests of both lending, to promote the development of rural financial and legal norms.

In summary, the development stage of China's rural financial lag, to bring a negative impact on the further development of agricultural production in our country, by strengthening the concept of rural financial development, strengthen internal financial system construction, attaches great importance to the development and external financial system to strengthen the innovation of rural financial products and other measures, to further improve China's rural financial service system, to lay a solid the foundation for the sustainable development of agriculture in china.

Relying on public finance funds, the establishments of rural financial risk reserve. Overall, China's rural financial development is still in its initial stage, the business network is relatively small, so the risk of financial institutions is not. But with the continuous development of rural finance, the risk will not be ignored; the particularity of agricultural production and rural areas on the development process of rural finance in China must pay attention to the appropriate risk prevention, in order to maintain the sustainable development of rural finance. Based on this, the establishment of the annual business tax and income tax from the rural financial institutions, in accordance with the $1 \%$ standard to extract the risk reserve, while local finance can contribute some of the funds to supplement. Risk reserve is mainly used to support the development of rural financial institutions in poor rural areas, rural insurance business, in order to deal with the possible risks in the process of the operation of rural financial institutions. Through this, it can also stimulate the rural financial institutions to participate in agricultural loans business, the driving force of agricultural insurance business, to promote sustainable development. 


\section{References}

[1] Mookerjee, R. and P. Kalipioni, 2010, Availability of Financial Services and Income Inequality: The Evidence from Many Countries [J], Emerging Markets Review 11(4):404-408.

[2] Hongbing Cai, Yuyu Chen and Li-an Zhou. Income and Consumption Inequality in Urban China: 1992-2003 [J] . Economic Development and Cultural Change.2010,Vol.58,No.3:385413.

[3] Buera, F., J. Kaboski, and Y. Shin (2011), Finance and Development: A Tale of Two Sectors, American Economic Review, 101, 1964-2002.

[4] Mikinnon, R. I. Money and Capital in Economic Development [M]. Washington DC: Brooking institution, 2010(2):75-96.

[5] Shaw,E.Financial Deeping in Economic Development[J].Oxford University Press,2011(4):89-109.

[6] King,R.G.,and Ross,L. Finance and Growth: Schumpter Might Be Right [J].Quarterly Journal of Economics,2012(8):717-738.

[7] Greenwood,J., and Jovanovic, B.Financial Development, Growth, and the Distribution of Income[J],Journal of Political Economy2013(5):1076-1107.

[8] Aghion, P.,Bolton,P. A theory of trickle-down growth and development [J].Review of Economics Studies, 2014(2):.151-172.

[9] Townsend, R.M., and Kenichi,U. Financial Deepening Inequality and Growth A Model-Based Quantitative Evaluation MF Working Paper 2013(3):193-194.

[10]Bourguignon, F., and Verdier, T.Oligarchy, democracy, inequality anf growth[J].Journal of Development Economics,2010(2):285-313. 